Transactions of the Karelian Research Centre of the Russian Academy of Sciences

No. 6. 2020. P. 97-105

DOI: $10.17076 /$ them 1255
Труды Карельского научного центра РАН

№ 6. 2020. С. 97-105

УДК $550.4+550.8 .05+550.84$

\title{
SHUNGITE ROCKS OF VARYING GENESIS IN INNOVATIVE WATER TREATMENT TECHNOLOGIES
}

\author{
V. V. Kovalevski ${ }^{1}$, S. -P. Reinikainen ${ }^{2}$, V. Reinikainen ${ }^{3}$, \\ V. S. Rozhkova ${ }^{1}$, T. Sihvonen ${ }^{2}$ \\ ${ }^{1}$ Institute of Geology, Karelian Research Centre RAS, Petrozavodsk, Russia \\ ${ }^{2}$ LUT University, Lappeenranta, Finland \\ ${ }^{3}$ Environmental Office of Lappeenranta Region, Finland
}

It is becoming increasingly important to deal with environmental pollution issues using ecologically safe processes based on natural mineral and biological components. The paper presents the results of research on shungite rocks of varying genesis to be used in innovative methods of water purification in combination with useful microbiota, effective microorganisms (yeast, lactic acid bacteria, etc.). It is shown that rocks at different stratigraphic levels (second, fourth and sixth), differing in composition and structure, are characterized by different degrees of leaching of chemical elements, sorption activity to cationic and anionic complexes, and differ in the ability to sorb polluting components from water, including heavy metals. It was found that unmodified shungite rock inhibits the functioning of effective microorganisms in direct contact, while for heat-treated shungite rock, on the contrary, a growth of effective microorganisms is observed.

Ke yw ords: shungite rocks; water purification; leaching; sorption activity; biological treatment; effective microorganisms.

\section{В. В. Ковалевский, С.-П. Рейникайнен, В. Рейникайнен, В. С. Рожкова, Т. СИХвоНЕН. ШУНГИТОВЫЕ ПОРОДЫ РАЗЛИЧНОГО ГЕНЕЗИСА В ИННОВАЦИОННЫХ ТЕХНОЛОГИЯХ ВОДООЧИСТКИ}

В последнее время все более актуальным становится решение проблем загрязнения окружающей среды с помощью экологически безопасных процессов на основе природных минеральных и биологических компонент. В работе приводятся результаты исследования шунгитовых пород различного генезиса для применения в инновационных способах очистки воды с совместным использованием полезной микробиоты, эффективных микроорганизмов (дрожжей, молочнокислых бактерий и пр.). Показано, что породы различных стратиграфических уровней (второго, четвертого и шестого), различающиеся по составу и строению, характеризуются разной степенью выщелачивания химических элементов, сорбционной активностью к катионным и анионным комплексам и по-разному способны сорбировать из воды загрязняющие компоненты, в том числе тяжелые металлы. Установлено, что немодифицированная шунгитовая порода ингибирует функционирование эффективных микроорганизмов при непосредственном контакте, а для термически обработанной шунгитовой породы, напротив, наблюдается рост эффективных микроорганизмов.

Ключев ы е с ло в а: шунгитовые породы; очистка воды; выщелачивание; сорбционная активность; биологическая очистка; эффективные микроорганизмы. 


\section{Introduction}

Shungite rocks are ancient Precambrian carbon-bearing rocks of Karelia (Russia), whose specific properties are due to the structure and properties of carbon (shungite) on the one hand, and on complex (varying from siliceous, aluminosilicate and carbonate to mixed) mineral composition on the other [Shungites..., 1975; Buseck et al., 1997]. Shungite rocks comprise, in addition to carbon, a wide range of macro and microelements. Previously, it was found that macroelements ( $\mathrm{Si}$, $\mathrm{Fe}, \mathrm{Ti}, \mathrm{Al}, \mathrm{Ca}, \mathrm{Mg}, \mathrm{Mn}, \mathrm{K}, \mathrm{Na}$ ) are mainly included in rock-forming minerals such as quartz, mica, chlorite, albite, calcite and dolomite, while microelements (Cu, Zn, Co, Ni, Cr, V, Mo, Pb, S, As, Se, etc.) are associated with accessory, mainly sulfide minerals. Among them are pyrite, violarite, chalcopyrite, sphalerite, millerite and others, as well as layered silicates, roscoelite and paragonite [Romashkin et al., 2014].

Based on the geological understanding of the Onega synclinorium structure, nine stratigraphic horizons of shungite rocks were conventionally identified as the most free-carbon-rich sections of the stratified strata [Kupryakov, 1988]. Currently, there are different ideas about the initial substance of shungite rocks and the conditions for its transformation. It is known that the processes of their formation occurred in the conditions of the greenshale facies of metamorphism, at a temperature of no more than $450^{\circ} \mathrm{C}$ and a pressure of no more than 7 kbar. However, in these ranges of temperatures and pressures, thermal and hydrothermal processes were manifested to varying degrees, which led to a wide variation in the composition, structure and properties of shungite rocks in different deposits and outcrops, even within the same stratigraphic horizon. At the same time, the conditions in which shungite rocks formed and transformed also influenced changes in the structural characteristics and properties of carbonaceous matter of the shungite rocks [Chazhengina et al., 2017; Deines et al., 2020].

Shungite rocks have a number of multifunctional physical and chemical properties, which determine the prospects for their practical use in metallurgy as coke, in chemistry as a catalyst, in water purification as an effective sorbent, and as an active filler of composite materials [Shungites..., 1975; Kalinin et al., 2008]. Recently, the prospects for the use of shungite rocks in agriculture and animal husbandry have been shown, in particular, due to increased plant resistance to drought [Kim et al., 2019].

One of the most cost-effective and environmentally justified practical uses of shungite rocks is their application as a sorbent and filter material in water purification and water treatment for both industrial and household needs, especially in the light of modern requirements to environmental problems [Shishkov, 2020]. Shungite as a sorbent features a number of positive characteristics: high mechanical strength and low abrasion; high filtering capacity (processability, due to low pressure resistance); the ability to sorb many substances, both organic (petroleum products, benzene, phenol, pesticides, etc.) and mineral (iron, manganese, phosphorus, arsenic) [Kalinin et al., 2008]. Shungite is able to clean water from petroleum products to the maximum permitted concentration (MPC) in water discharged to fisheries reservoirs. At the same time, shungite as a strong reducing agent absorbs oxygen from water with the formation of atomic oxygen, which oxidizes the sorbed organic substances to $\mathrm{CO}_{2}$ and $\mathrm{H}_{2} \mathrm{O}$, making the surface of shungite available for new sorption acts [Kalinin et al., 2008].

In general, shungite rocks exhibit the ability to sorb both inorganic cations and anions. Moreover, the cation exchange function dominates in alkaline, and the anion-exchange function - in acidified solutions. Organic acids are significantly better sorbed, and other things being equal, shungite selectively sorbs aromatic acids [Shalimov et al., 2004]. As to the sorption of heavy metals, it is shown that natural and thermally modified shungite rocks have a high adsorption capacity with respect to iron (III) cations in comparison with other carbon sorbents [Alekseev et al., 2016]. They also have sorption and reducing properties when cleaning water from chromium [Shchetinskaya et al., 2017].

It is also important that shungite rock has demonstrated a high sorption activity in relation to pathogenic microflora. When the contaminated water of Lake Onega containing pathogenic saprophytes and protozoa (infusoria, rotifers, crustaceans) was passed through shungite filter, almost complete removal of Escherichia coli (a change in the coli index from $2300 \mathrm{KL} / \mathrm{I}$ to less than $3 \mathrm{KL} / \mathrm{I}$ ) and protozoa (from $1785 \mathrm{KL} / \mathrm{I}$ to $0 \mathrm{KL} / \mathrm{l}$ ) was observed, securing conformance to sanitary standards [Zaguralskaya, 1990]. At the same time, in natural conditions, shungite rocks are characterized by a symbiosis with microbiota, containing a wide range of non-pathogenic microorganisms, in particular, chemoorganotrophic, methylotrophic and chemolithotrophic bacteria. The dominant phylotypes include 3 phyla (Proteobacteria, Actinobacteria and Firmicutes), with the bulk of the microbiome constituted by Proteobacteria (76.4 to $81.2 \%$ ) [Sidorova et al., 2019].

Unfortunately, for many consumers, the term "shungite" and "shungite rock" refers only 
to the rock determined by its carbon content, without any attention to the structure of carbon, mineral components, and the rock as a whole, without taking into account the wide variety of shungite rocks, which differ in the conditions of formation and, as a result, in the structure and physical and chemical properties. Therefore, it is not surprising that the study and application of shungite rocks reveal diametrically opposite properties, previously conducted studies are not confirmed, and previously described effects are not achieved in industrial areas. For example, in a study of the effect of an aqueous extract of shungite rock on microorganisms for the purpose of their neutralization, pronounced signs of destruction of bacterial cells have been shown [Ponomarev, 2018]. At the same time, results are presented that do not confirm the effectiveness of "shungite" in disinfecting water from bacteria, moreover, when "shungite" was added to experimental tanks, the number of microorganisms not only did not decrease, but on the contrary, increased [Dallakyan et al., 2017].

Thus, the aim of this work is to study geologically bound shungite rocks with different composition, structure and properties and to establish criteria for their selection as industrial mineral raw materials to be used in innovative water purification schemes as a potential filter material in combination with effective microorganisms.

\section{Characteristics of the research objects}

The study objects were shungite rocks of the Onega synclinorium, developed in the sixth (first and second samples), second (third sample) and fourth (fourth sample) shungite-bearing horizons with a carbon content of 34 to $48 \%$.

\section{Material and methods}

The content of petrogenic elements in samples was determined by quantitative chemical analysis methods in the analytical laboratory of the Institute of Geology KarRC RAS (Petrozavodsk). The data from the chemical analyses were recalculated on a carbon-free basis (the mineral component of shungite rocks). The mineral composition was determined using $\mathrm{X}$-ray phase analysis.

The adsorption activity of shungite rocks from various stratigraphic levels was measured by the adsorption of methylene blue and methanyl yellow from aqueous solutions. The amount of the dye absorbed from the solution by the sample material (fraction $>1 \mathrm{~mm}$ ) under static conditions was taken as the measure of activity. The dye concentration in the solution was determined using Raman spectroscopy following a procedure described elsewhere [Rozhkova et al., 2019].

The study of leaching processes in shungite rocks, the analysis of various elements, the study of sorption of shungite rocks on model solutions at different concentrations were conducted at LUT University (Lappeenranta) using ICP-MS. The preliminary testing of shungite rocks for environmental acceptability was done according to Finnish Government Decree on landfills 331/2013. Experiments on the biocompatibility of shungite rocks and useful microorganisms on unmodified and heat-treated $\left(400^{\circ} \mathrm{C}\right)$ shungite rocks were carried out at LUT University and IG KarRC RAS.

\section{Results and discussion}

The use of shungite rocks as a filter material in combination with effective microorganisms implies the fulfillment of a number of criteria. First, regarding the degree of leaching of dangerous concentrations of chemical elements from the shungite rocks themselves, second, regarding the sorption activity of the filter material as applied to potential polluting complexes of anionic and cationic character, and finally, regarding the compatibility of shungite rocks with effective microorganisms.

Leaching of chemical elements from shungite rocks is governed by a number of factors. As previously shown for water purification using shungite rocks, both sorption and leaching properties of $\mathrm{SH}$ are important. Those are determined by the type of shungite rocks, content and composition of carbon and minerals, and their structure and physicochemical properties (the value of the specific surface and its chemical state, for instance). It should be noted that the aqueous extracts of different shungite rocks differ in ionic and microcomponent composition. Leaching of components from the mineral part of different shungite rocks is determined not only by the composition of the rock but also by the $\mathrm{pH}$ value. Namely, the lower the $\mathrm{pH}$, the greater the rate of hydrolytic processes separating minerals, in particular sulphides. However, the content of certain elements ( $\mathrm{Na}, \mathrm{Ca}$ ) in the solutions does not depend on the acidity of the medium and their content in the rocks [Rozhkova et al., 2012].

Chemical analysis of the selected samples showed that, being similar in carbon content, rocks differ slightly in the content of the main chemical elements, and quite significantly in the composition of rock-forming minerals (Table).

One of the most important indicators of the interaction of shungite rocks with water is the hydrogen index $(\mathrm{pH})$. For the selected rocks, the $\mathrm{pH}$ had different values, according to the generally accept- 
Chemical and mineralogical composition of shungite rocks and $\mathrm{pH}$ of the aqueous extract from them

\begin{tabular}{|c|c|c|c|c|}
\hline \multirow{2}{*}{$\begin{array}{l}\text { Composi- } \\
\text { tion }\end{array}$} & \multicolumn{4}{|c|}{ Shungite rock } \\
\hline & $\begin{array}{c}\# 1 \\
\text { horizon } 6\end{array}$ & $\begin{array}{c}\# 2 \\
\text { horizon } 6\end{array}$ & \begin{tabular}{|c|}
3 \\
horizon 2
\end{tabular} & \begin{tabular}{|c|}
4 \\
horizon 4
\end{tabular} \\
\hline \multicolumn{5}{|c|}{ Chemical composition, oxides, \% } \\
\hline $\mathrm{SiO}_{2}$ & 52.28 & 40.78 & 30.99 & 38.6 \\
\hline $\mathrm{TiO}_{2}$ & 0.21 & 0.28 & 0.42 & 0.34 \\
\hline $\mathrm{Al}_{2} \mathrm{O}_{3}$ & 3.56 & 5.11 & 6.96 & 7.02 \\
\hline $\mathrm{Fe}_{2} \mathrm{O}_{3}$ & 4.23 & 2.14 & 6.49 & 1.47 \\
\hline $\mathrm{FeO}$ & 0.53 & 0.53 & 2.93 & 0.53 \\
\hline $\mathrm{MnO}$ & 0.015 & 0.015 & 0.1 & 0.01 \\
\hline $\mathrm{MgO}$ & 1.11 & 0.94 & 5.46 & 1.03 \\
\hline $\mathrm{CaO}$ & 0.07 & $<0.01$ & 2.83 & 0.58 \\
\hline $\mathrm{Na}_{2} \mathrm{O}$ & 0.06 & 0.05 & 1.82 & 1.5 \\
\hline $\mathrm{K}_{2} \mathrm{O}$ & 0.54 & 1.20 & 0.22 & 1.87 \\
\hline $\mathrm{LOI}^{*}$ & 35.4 & 47.03 & 40.95 & 46.27 \\
\hline $\mathrm{P}_{2} \mathrm{O}_{5}$ & 0.10 & 0.05 & 0.07 & 0.14 \\
\hline $\mathrm{S}$ & 1.89 & 1.86 & 0.76 & 0.28 \\
\hline $\mathrm{C}^{\star \star}$ & 34 & 48 & 35 & 40 \\
\hline \multicolumn{5}{|c|}{ Mineralogical composition wt. \% } \\
\hline Quartz & 56 & 37 & 2 & 32 \\
\hline Muscovite & 6 & 12 & & 14 \\
\hline Pyrite & 2 & 3 & & \\
\hline Microcline & & & & 14 \\
\hline Actinolite & & & 34 & \\
\hline Albite & & & 19 & \\
\hline Kaolinite & & & 2 & \\
\hline Chlorite & & & 8 & \\
\hline \multicolumn{5}{|c|}{$p H$} \\
\hline $\begin{array}{l}0.1 \\
\text { hour*RUS }\end{array}$ & 5.4 & 3.4 & 5.9 & 6.1 \\
\hline $\begin{array}{l}24 \\
\text { hours }\end{array}$ & 4.3 & 3.1 & 5.4 & 4.9 \\
\hline $\begin{array}{l}0.1 \mathrm{~h} / 24 \mathrm{~h} / \\
28 \\
\text { days ** Rus }\end{array}$ & $4.5 / 4.3 / 3.8$ & $4 / 3.5 / 3.3$ & $5.9 / 5.8 / 5.8$ & $5.5 / 4.8 / 4.7$ \\
\hline \multicolumn{5}{|c|}{ 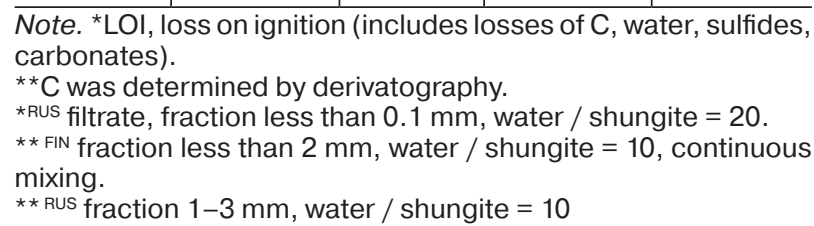 } \\
\hline
\end{tabular}

ed Russian express method (solid-liquid: $1: 10$, filtrate, about 5 minutes of exposure), ranging from 6.1 to 3.4 ( ${ }^{* \text { Rus }}$ in Table).

At the same time, measurements made in Finland (**FIN in Table) on fractions about $2 \mathrm{~mm}$ at 24-hour exposure differ significantly. Additional experiments conducted in Russia ( ${ }^{* * \text { Rus }}$ in Table) showed changes in $\mathrm{pH}$ over time. As the sample spent more time in water, the $\mathrm{pH}$ decreased to varying degrees for different shungite rocks and stabilized with slight variations after a few days (Table). Note that for samples 1 and 4 there is a complete correspondence in $\mathrm{pH}$ values obtained in Russia and Finland, and for samples 2 and 3 there is some difference. The $\mathrm{pH}$ differences may indicate both a greater heterogeneity of samples $2 \& 3$ and some differences in the leaching processes of anionic and cationic complexes among the selected samples. Naturally, these $\mathrm{pH}$ changes are observed only in a closed volume and have higher values in the presence of water flow. However, directly in the contact layer of shungite rock and water, $\mathrm{pH}$ affects the leaching of chemical elements from samples, their ion exchange reactions and sorption properties.

The results of experiments on the leaching of some chemical elements from shungite rocks in a closed volume are shown in Fig. 1. The total number of metals determined from the leachate with ICP-MS was 26, including phosphorus. Samples 1 and 2 showed fairly high degrees of leaching of chemical elements, among which the concentrations of $\mathrm{Ni}(0.4 \mathrm{mg} / \mathrm{kg})$ and $\mathrm{Zn}(4 \mathrm{mg} / \mathrm{kg})$ exceeded the permissible limits, and therefore they are not environmentally acceptable, nor can potentially become commercial fractions. In fact, shungite 2 exceeded also inert material values for leaching of $\mathrm{Cu}, \mathrm{Cd}$ and Se. However, non-hazard limits were not exceeded for any of these. Thus, the results obtained do not allow us to consider Shungite 1 and Shungite 2 as a filter material in static conditions or at low water consumption.

Data on the sorption activity of shungite rocks with respect to cationic and anionic complexes for the case of methylene blue (MB) and methanyl yellow (MY) are shown in Fig. 2. Sample 3 has the highest sorption activity for cationic complexes, and sample 2 has the lowest sorption activity. However, sample 2 has a higher sorption activity relative to anionic complexes, and sample 3 has a lower sorption activity. The adsorption properties of shungite rock are probably due to the combination of fine mineral components evenly distributed in the carbon matrix and the presence of various functional groups, which facilities the formation of adsorption centers of different nature.

To determine the sorption activity of shungite rocks for ions of various metals and complexes, a model mixture containing $\mathrm{Cu}-57.5 \mathrm{ppm}$, $\mathrm{Zn}-94.9 \mathrm{ppm}, \mathrm{Na}-96.3 \mathrm{ppm}$, and $\mathrm{P}-42.4 \mathrm{ppm}$ was used. The results of the experiment shown in Fig. 3 demonstrate the high efficiency of samples 3 and 4 for the sorption of $\mathrm{Cu}$ and $\mathrm{Zn}$, while negative values for the sorption of $\mathrm{Na}, \mathrm{Mg}$ and $\mathrm{Ca}$ indicate the leaching of these elements from the third sample during the experiments. Changes in the concentration of metals in the solution

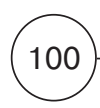



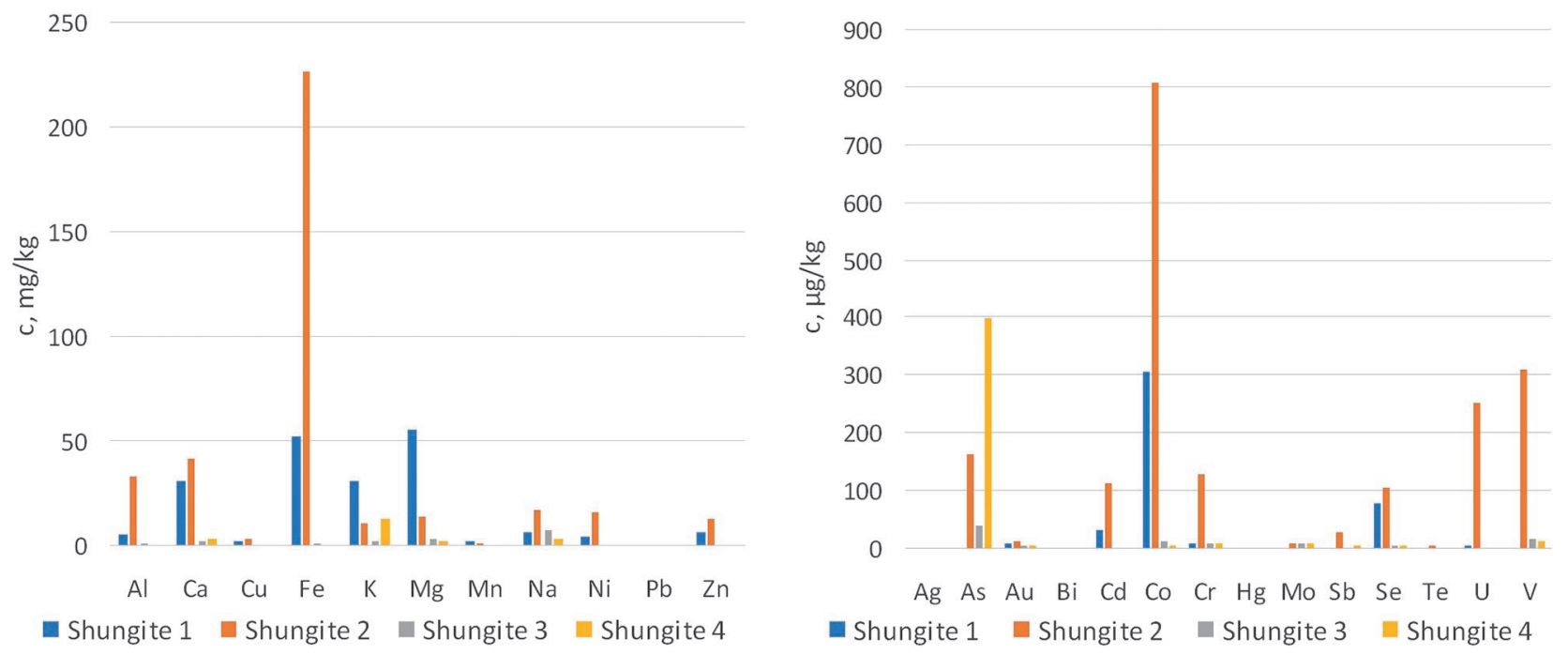

Fig. 1. Results for some metals from leaching test $(\mathrm{L} / \mathrm{S}=10)$. Inert waste had values at the threshold, for example regarding Ni $(0.4 \mathrm{mg} / \mathrm{kg})$, and Zn ( $4 \mathrm{mg} / \mathrm{kg})$. Therefore shungite samples 1 and 2 would not be environmentally feasible in Finland, or activation with thermal or chemical treatment would be required

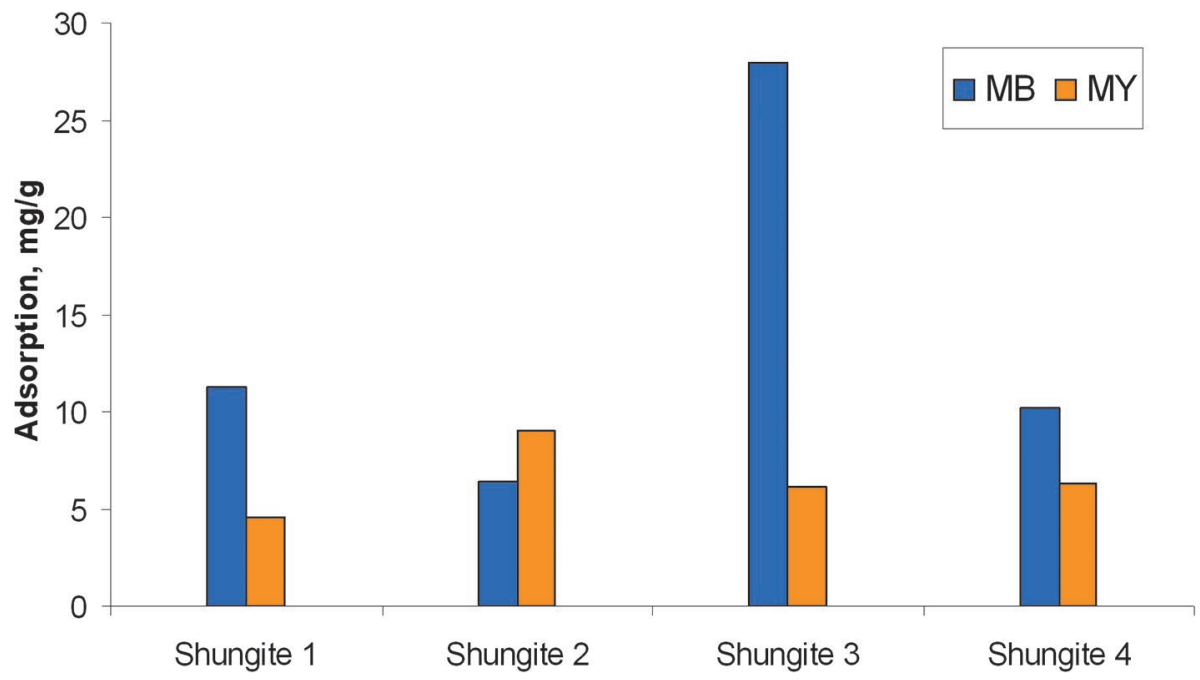

Fig. 2. Sorption activity of shungite rocks with respect to cationic and anionic complexes for the case of methylene blue (MB) and methanyl yellow (MY) for shungite 1, 2, 3 and 4

affect the sorption efficiency (Fig. 4). At the same time, based on the sorption kinetics, it follows that ion-exchange processes occur very quickly and do not require a long contact time.

The compatibility of shungite rocks with effective microorganisms is of particular interest. Previously, it was found that shungite rocks have sorption activity in relation to pathogenic microflora [Zaguralskaya, 1990]. This effect may be related to the chemistry of shungite rock, in particular the content of trace elements, lanthanides, which cause selective coagulation of bacterial cells by complexing lanthanide cations with nucleic acids of microorganisms through phosphate groups [Ponomarev et al., 2017]. It can also be explained by the presence of natural biotopes long associated with shungite rocks, such as chemoorgano- trophic, methylotrophic and chemolithotrophic bacteria (Proteobacteria, Actinobacteria and Firmicutes) [Sidorova et al., 2019], suppressing the reproduction of "foreign" microorganisms.

Experiments conducted at LUT University have shown that shungite rock inhibits the functioning of effective microorganisms, unlike, for example, ceramics. Moreover, the growth of own microorganisms present on shungite increases. That does not allow shungite and effective microorganisms to be used together in direct contact. However, heat-treated shungite rock proved to be compatible with effective microorganisms, since their growth is observed on the surface (Fig. 5).

The use of effective microorganisms involves the destruction of dissolved organic compounds by microorganisms. In this case, some of the sub- 


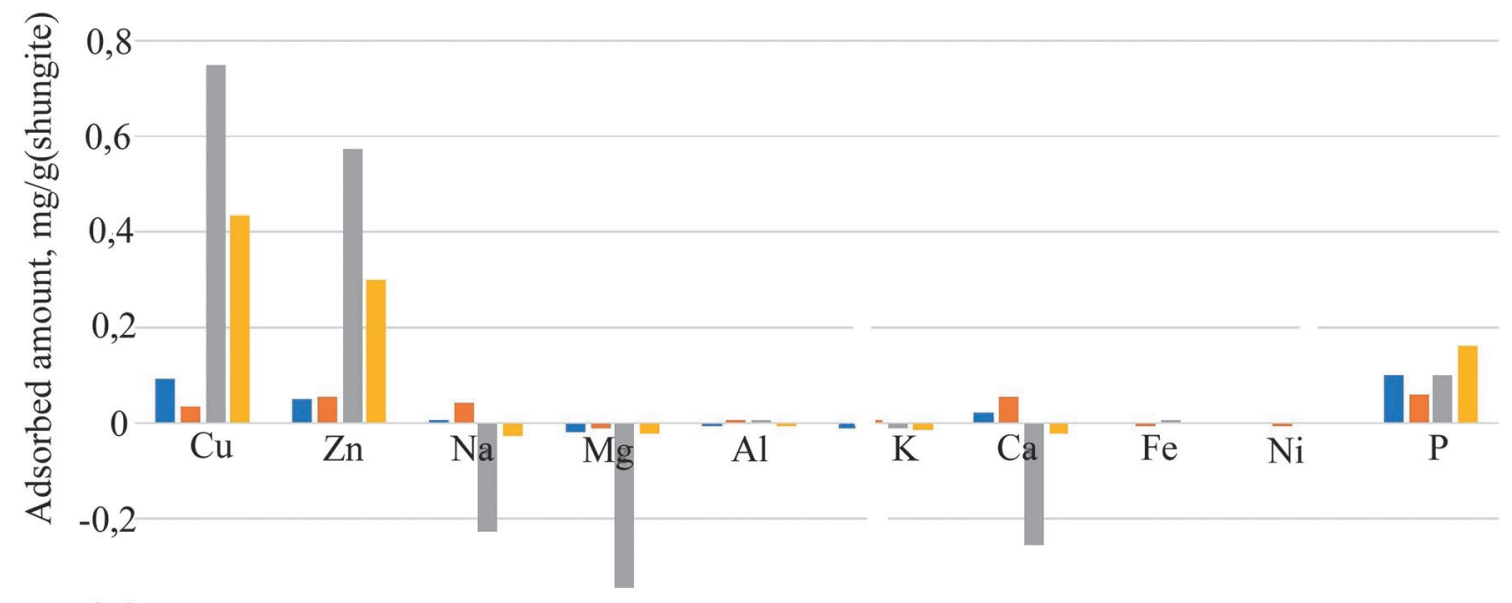
$-0,4$

$\varpi$ Shungite $1 \varpi$ Shungite $2 \varpi$ Shungite $3 \varpi$ Shungite 4

Fig. 3. Results of the metals adsorption test. The results are in $\mathrm{mg} / \mathrm{g}$ (shungite). Negative bars indicate that the element in question has been released from the shungite during the adsorption experiment

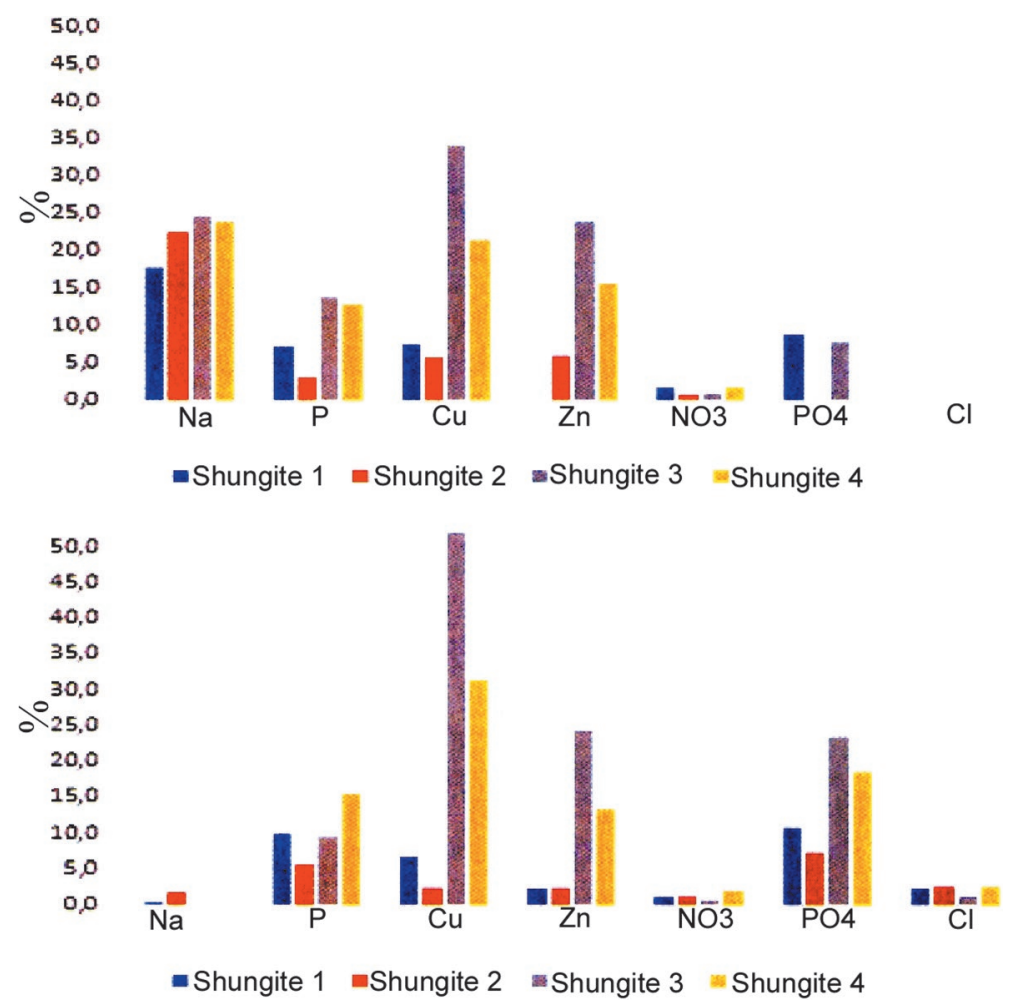

Fig. 4. Results of the metals adsorption test. The results are given in $\%$ for a) high concentration, and b) lower concentration of the metals. Adsorption mechanisms are affected by the ion concentration in the solution $(\mathrm{Na})$. Nitrate removal is inefficient with any shungite fraction studied

stances are mineralized, while others are used by microbes in constructive metabolism, resulting in a significant increase in their concentration in the treated water. Secondary water pollution happens. Living microorganisms themselves become a source of contamination, even in the case of complete non-pathogenicity, and contribute to the eutrophication (blooming) of waters. Therefore, biological treatment must be accompanied by the removal of microorganisms.

One of the methods for removing microorganisms from the water is the adsorption of microorganisms onto the surface of solids. In this regard, effective sorption of microorganisms, including

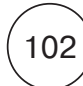



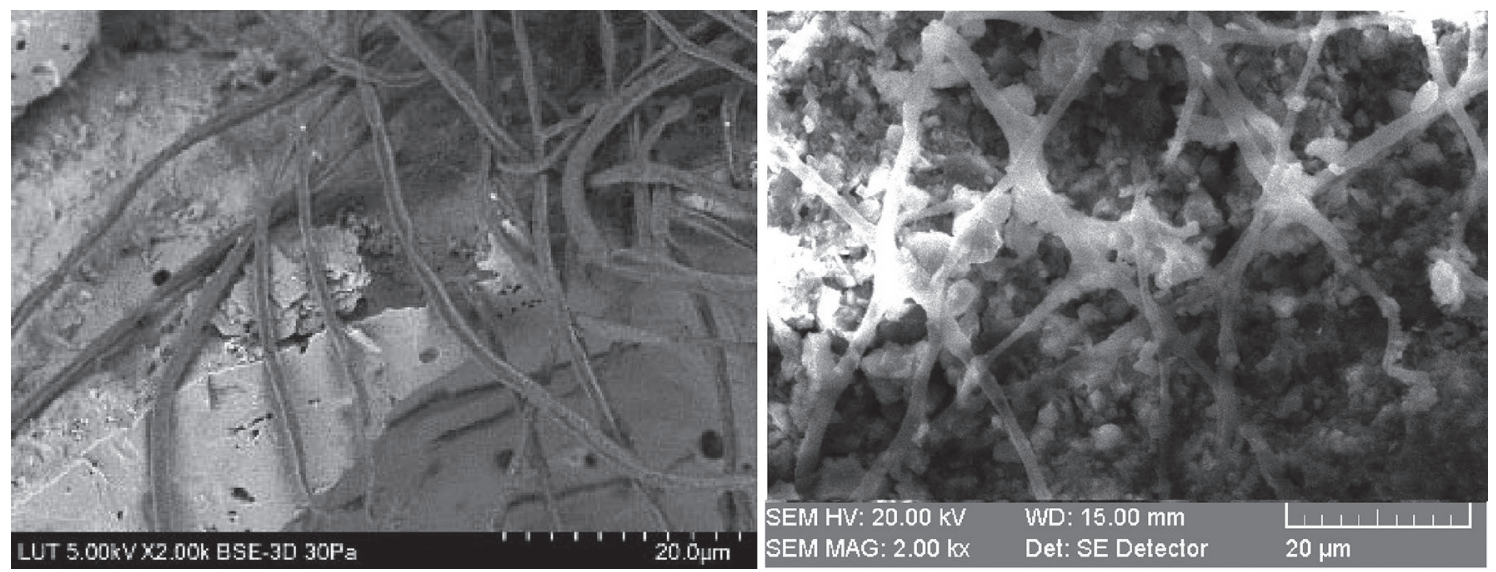

Fig. 5. Effective microorganisms on the surface of ceramics (LUT University) and thermally $\left(400{ }^{\circ} \mathrm{C}\right.$ ) modified shungite rock (IG KarRC RAS)

effective microorganisms, can be a positive effect in a two-stage water purification process. For example, at the first stage, water passes through a layer of ceramics (and/or thermally modified shungite rock) as a carrier of effective microorganisms. At the second stage, which involves unmodified shungite rock, not only various undesirable chemical impurities, but also various members of the microflora and effective microorganisms are removed by sorption.

An important feature of shungite rock is the possibility of regeneration, which enables an extension of the service life of the material as a sorbent. In particular, when studying the sorption of higher alcohols and other impurities from water-alcohol solutions, the formation of sufficiently strong adsorption systems was detected, which, however, decompose completely at $180^{\circ} \mathrm{C}$ heat treatment in the vacuum, which leads to regeneration and some increase in the surface and sorption volume of shungite. This effect of restoring the adsorption centers on the surface of shungite was observed during five sorption cycles [Mel'nik et al., 2017].

Thus, the study allows us to use the identified patterns not only to determine the criteria for selecting the most effective industrial types of shungite rocks for water treatment, but also to substantiate possible water purification setups and filter elements setups.

\section{Conclusions}

Shungite rocks of the sixth, fourth and second stratigraphic levels of the Zaonezhskaya formation of the Paleoproterozoic era in Karelia were studies with view to their potential application in innovative water purification setups as a potential filter material in combination with useful microbiota (yeast, lactic acid bacteria, etc.). It is shown that shungite rocks of the sixth level have a higher degree of leaching of various chemical elements from them. Among the studied samples, the maximum sorption activity was found in the more alkaline and less siliceous rock of the second level, which sorbs higher concentrations of heavy metals. Shungite rock not subjected to any thermal or chemical treatment inhibits the reproduction of useful microbiota, but after heat treatment it shows good compatibility with this microbiota, like ceramics.

Based on our results, rock from the second stratigraphic level appears to be the most promising as a filter material. At the same time, a twostage filter is assumed to be optimal for water treatment. The first layer should consist of a ceramic or heat-treated shungite rock, with an effective functioning of useful microbiota that recovers a wide range of contaminants from the water. The second layer is untreated shungite rock, which absorbs heavy metals and some organic compounds, and disinfects water from microorganisms to prevent eutrophication.

The research was carried out within the framework of the KS1460 (SHEM-WP), ENI SouthEast Finland - Russia CBC Programme, and with financial support from the Federal budget for the implementation of the state order to KarRC RAS (IG KarRC RAS, research topic no. AAAA-A18-118020690238-0, to VVK and VSR).

\section{References}

Alekseev A. I., Churkina O. S., Golubev P. V. Study of chemistry of sorption of iron (III) cations by carbon-containing compounds. Proceed. St. Petersburg St. Tech. Inst. (Tech. Univ.). 2016. No. 36(62). P. 48-51. (In Russ.) 
Buseck P. R., Galdobina L. P., Kovalevski V. V., Rozhkova N. N., Valley J.W., ZaidenbergA.Z. Shungites: the C-rich rocks of Karelia, Russia. Can. Mineral. 1997. Vol. 35(6). P. 1363-1378.

Chazhengina S. Yu., Kovalevski V. V. Raman spectroscopy of weathered shungites. J. Raman Spectroscopy. 2017. Vol. 48(11). P. 1590-1596. doi: 10.1002/ jrs. 5188

Deines Yu. E., Kovalevski V. V., Kochneva I. V., Moshnikov I. A., Rozhkova V. S. Physical and chemical properties of shungite rocks from different stratigraphic levels of the Zaonezhye suite. Trans. KarRC RAS. 2020. No. 2. P. 84-89. doi: 10.17076/geo1187. (In Russ.)

Dallakyan G. A., Mosharova I. V., II'inskii V. V. Influence of schungite on the number of bacterioplankton during the experiments in vitro. Public Health and Life Environ. 2017. No. 11(296). P. 16-19. (In Russ.)

Kalinin Yu. K., Kalinin A. I., Skorobogatov G. A. Shungites of Karelia - for new building materials, in chemical synthesis, gas treatment, water treatment and medicine. St. Petersburg: UNC SPBU, VVM, 2008. 219 p. (In Russ.)

Kim T. Y., Lee S.-H., Ku H., Lee S.-Y. Enhancement of drought tolerance in cucumber plants by natural carbon materials. Plants. 2019. Vol. 8(11). P. 446-461. doi: $10.3390 /$ plants8110446

Kupryakov S. V. Report on the results of search operations conducted in the Onega structure in 1985-1988. Petrozavodsk, 1988. 148 p. (In Russ.)

Mel'nik L.M., TkachukN.A., TurchunO. V., Diyuk V. E., IschenkoO. V., ByedaO. O., Kisterska L. D. Loginova O. B., Lysovenko S. O., Gontar O. G., Garashchenko V. V. Adsorption properties of shungite in purification of water - alcohol solutions. J. Superhard Mat. 2017. Vol. 39(6). P. 416-421. doi: 10.3103/ S1063457617060053

Ponomarev A. P., Podolets A. A., Makina O. A. The use of aqueous extract of shungite mineral for the removal of bacterial flora from water. Water Supply and Sanitary Technique. 2017. No. 9. P. 17-24. (In Russ.)

Ponomarev A. P. Aqueous extract of shungite mineral - a complexing agent for microorganisms in aqueous

\section{СВЕДЕНИЯ ОБ АВТОРАХ:}

\section{Ковалевский Владимир Викторович}

заведующий лаб. геологии и технологии шунгитов

Отдела минерального сырья, д. г.-М. н.

Институт геологии КарНЦ РАН

Федеральный исследовательский центр

«Карельский научный центр РАН»

ул. Пушкинская, 11, Петрозаводск, Республика Карелия, Россия, 185910

эл. почта: kovalevs@krc.karelia.ru

\section{Рейникайнен, Сату-Пиа}

профессор

Технологический университет Лаппеенранта

Лаппеенранта, Финляндия, FIN-53850

эл. почта: Satu-pia.reinikainen@lut.fi solution purification. Water Supply and Sanitary Technique. 2018. No. 7. P. 11-17. (In Russ.)

Romashkin A. E., Rychanchik D. V., Golubev A. I. $R E E$ geochemistry of carbonaceous rocks in the Onega structure. Geol. and Minerals of Karelia. 2014. Iss. 17 P. 74-85. (In Russ.)

Rozhkova V. S., Kovalevski V. V., Kochneva I. V., Lozovik P. A. About possibility of use of shungite rocks of Karelia in water conditioning. Mining J. 2012. No. 5. P. 64-67. (In Russ.)

Rozhkova V. S., Kovalevski V. V. Determination of adsorption of cationicandanionic dyes onto shungite by Raman spectroscopy. Spectroscopy. 2019. Vol. 34(7). P. 45-54. URL: $\quad$ http://www.spectroscopyonline.com/determination-adsorption-cationic-and-anionic-dyes-shungite-raman-spectroscopy (accessed: 18.05.2020).

Shalimov A. S., Kovalevski V. V., ObrezkovO. N., Yaroslavtsev A. B. Sorptive properties of shungite. Inorganic Mat. 2004. Vol. 40(4). P. 364-367. doi: 10.1023/ B:INMA.0000023956.54637.b8

Shishkov A. Yu. Emerging prospects of mining waste utilization in the Karelian-Kola region. Trans. KarRC RAS 2020. No. 2. P. 90-97. doi: 10.17076/geo1182 (In Russ.)

Shungites of Karelia and ways of their all-purpose utilization. Eds. Sokolov V. A., Kalinin Yu. K. Petrozavodsk: Karelia, 1975. 240 p. (In Russ.)

Sidorova N. A., Savushkin A. I., Trofimova S. A., Kovalevski V. V. Biodiversity of aborigental bacterial communities in the shungites of the Onega structure. Environ. probl. of the northern regions and ways to solve them. (June 16-22, 2019, Apatity. Russia). Apatity: Kola RC RAS, 2019. P. 256-257. (In Russ.)

Szczetinskaya O. S., Soboleva O. A. The purification of waste water from chromium compounds with shungite. Bull. Tech. Univ. 2017. Vol. 20(20). P. 128-132. (In Russ.)

Zagural'skaya L. M. Report T. 97. Microbiological control of the degree of wastewater treatment with shungite rocks. Petrozavodsk: KarRC of the USSR Acad. Sci., 1990. 22 p. (In Russ.)

Received May 21, 2020

\section{CONTRIBUTORS:}

\section{Kovalevski, Vladimir}

Institute of Geology, Karelian Research Centre, Russian Academy of Sciences

11 Pushkinskaya St., 185910 Petrozavodsk, Karelia, Russia e-mail: kovalevs@krc.karelia.ru

\section{Reinikainen, Satu-Pia}

LUT University, Lappeenranta, Finland Yliopistonkatu 34, FIN-53850 Lappeenranta, Finland e-mail: Satu-pia.reinikainen@lut.fi 
Рейникайнен, Вилле

менеджер проектов

Экологическое управление региона Лаппеенранта

Лаппеенранта, Финляндия, FIN-53100

эл. почта: Ville.reinikainen@lut.fi

\section{Рожкова Виктория Сергеевна}

ведущий химик

Институт геологии КарНЦ РАН,

Федеральный исследовательский центр

«Карельский научный центр РАН»

ул. Пушкинская, 11, Петрозаводск, Республика Карелия,

Россия, 185910

эл. почта: vrozhk@krc.karelia.ru

\section{Сихвонен, Туомас}

исследователь

Технологический университет Лаппеенранта

Лаппеенранта, Финляндия, FIN-53850

эл. почта: Tuomas.sihvonen@lut.fi
Reinikainen, Ville

Environmental Office of Lappeenranta Region, Finland

Pohjolakatu 14, FIN-53100 Lappeenranta, Finland

e-mail: Ville.reinikainen@lut.fi

\section{Rozhkova, Victoria}

Institute of Geology, Karelian Research Centre,

Russian Academy of Sciences

11 Pushkinskaya St., 185910 Petrozavodsk, Karelia, Russia

e-mail: vrozhk@krc.karelia.ru

\section{Sihvonen, Tuomas}

LUT University, Lappeenranta, Finland

Yliopistonkatu 34, FIN-53850 Lappeenranta, Finland

e-mail: Tuomas.sihvonen@lut.fi 